\title{
THE ISOTOPIC SIGNATURE OF THE MINERALIZING FLUID OF THE LAVRION CARBONATE-REPLACEMENT PB-ZN-AG DISTRICT
}

\author{
Tombros S.F. ${ }^{1}$, St. Seymour K. ${ }^{1}$, Spry P.G. ${ }^{2}$ and Bonsall T.A. ${ }^{2}$ \\ ${ }^{1}$ University of Patras, Department of Geology, Laboratory of Volcanology and Ore deposits, 26500 Patras, \\ Greece,tompros@mailbox.gr, kstseymr@upatras.gr \\ ${ }^{2}$ Iowa State University, Department of Geological and Atmospheric Sciences, 253 Science I, Ames, Iowa \\ 50011-321,pgspry@iastate.edu.
}

\begin{abstract}
The Pb-Zn-Ag carbonate-replacement deposits in the Lavrion district are genetically related to a 710 Ma-old granodiorite, felsic dikes and sills. These deposits are hosted in the Upper and Lower marble and schists of the Cyclades Blueschist unit and occur along the major Legraina detachment fault. Carbonate-replacement orebodies occur as "mantos" and veins, dominated by base metal sulfides and $\mathrm{Ag}, \mathrm{Bi}, \mathrm{Sn}, \mathrm{Sb}, \mathrm{As}$, and $\mathrm{Pb}$ sulfosalts. Calculated carbon and oxygen isotope compositions of the hydrothermal fluid range from $\delta^{13} \mathrm{C}_{\mathrm{CO} 2}$ of -13.7 to $0.8 \mathrm{per}$ mil and $\delta^{18} \mathrm{O}_{\mathrm{H} 2 \mathrm{O}}$ of 4.2 to 27.4 per mil, at $400^{\circ}, 350^{\circ}, 320^{\circ}, 300^{\circ}, 250^{\circ}$ and $200^{\circ} \mathrm{C}$. These isotopic compositions reveal water-torock ratios ranging from 4.8 to $52.6 \%$, which reflect intense interaction of the ore fluid with the host rock in a water-dominated, transitional closed to open hydrothermal system.

The range of $\delta^{34} S_{H 2 S}$ for sulfides in the deposits were from -8.5 to 6.8 per mil, for similar temperatures, whereas for barite-fluorite veins from $\delta^{34} S_{H 2 S}$ of -43.6 to $-16.4 \mathrm{per}$ mil, at $200^{\circ}, 150^{\circ}$ and $100^{\circ} \mathrm{C}$. This range implies that there was contribution from a magmatic sulfur component exsolved from the Plaka pluton, as well as contribution from a metasedimentary component. Based on the isotopic signature of sulfur for barite, the $\log \frac{a_{\mathrm{SO}_{4}^{-2}(\text { aq) }}}{a_{\mathrm{H}_{2} \mathrm{~S}_{(\mathrm{aq})}}}$ ranges from -6.7 to -7.6, comprising an increase in the fluid influx. Isotopic temperatures based on pyrite-galena and sphalerite-pyrite pairs revealed at least three major events of carbonate-replacement ore deposition, (i) at $\sim 360^{\circ}$, (ii) $320^{\circ}-280^{\circ}$ and (iii) $260^{\circ}-200^{\circ} \mathrm{C}$.
\end{abstract}

Key words: polymetallic ores, ore fluid, carbon, oxygen, sulfur isotopes.

\section{Introduction}

The Lavrion district is famous for the production of $\mathrm{Pb}(\sim 1.4 \mathrm{Mt}$, at $20 \%)$ and $\mathrm{Ag}(\sim 3.5 \mathrm{kt}$, at 400 $\mathrm{g} / \mathrm{t}$ ) since the Golden Age of Athens (Conofagos, 1980). Recent mining in this area was mainly conducted by Compagnie Françoise des Mines du Laurium ( $0.9 \mathrm{Mt}$, at 3\% Pb and $4.2 \mathrm{kt} \mathrm{Ag}$, at 140 $\mathrm{g} / \mathrm{t}$, Conofagos, 1980). The area is considered as the northern part of the Cycladic Blueschist Belt, which is one of the most spectacular Alpine orogenic belts worldwide (Blake et al., 1981). Within this belt, various types of base and precious metal ores including skarn (i.e., Serifos, Lavrion and 


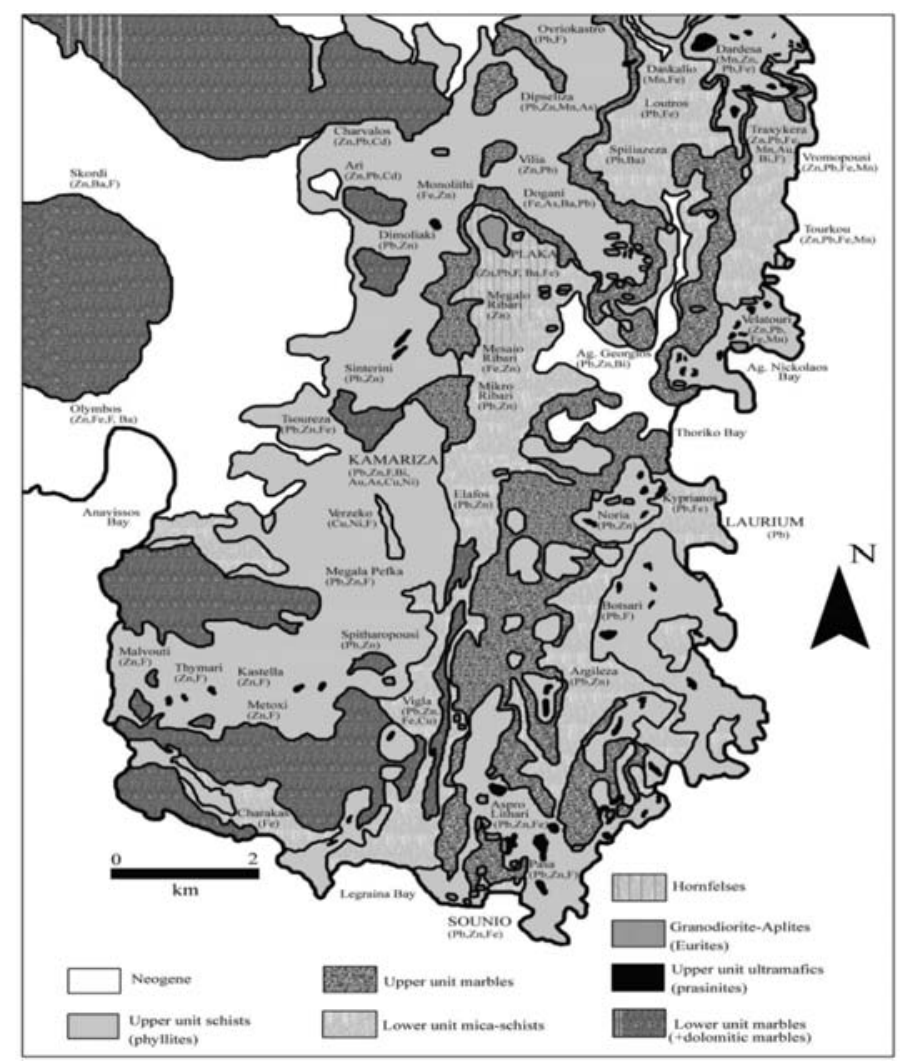

Fig. 1: Simplified geological and ore deposits map of Lavrion (modified after Marinos and Petrascheck, 1956).

Tinos), epithermal veins (i.e., Lavrion, Antiparos, Tinos, Mykonos and Ikaria), and carbonate-replacement deposits (i.e., Lavrion and Sifnos) were reported by Melidonis, (1980), Salemink (1985), Skarpelis (2002), Voudouris et al. (2008a, b), Tombros et al. (2007; 2008; 2009) and St. Seymour et al. (2009a, b). In addition to the above ore styles, a porphyry- and breccia-hosted and supergene mineralization has also been identified in the Lavrion district (Bonsall et al., 2007). Different genetic models have been proposed for the formation of the carbonate-replacement $\mathrm{Pb}-\mathrm{Zn}$ - $\mathrm{Ag}$ deposits at Lavrion i.e., granitoid-related (Leleu, 1966), Mississippi Valley- (Kalogeropoulos and Mitropoulos, 1983) and manto-type (Skarpelis, 2002). The present study investigates the provenance of the Lavrion mineralizing fluid, based on the calculated values of its $\delta^{13} \mathrm{C}_{\mathrm{CO}_{2}}, \delta^{18} \mathrm{O}_{\mathrm{H}_{2} \mathrm{O}}$ and $\delta^{34} \mathrm{~S}_{\mathrm{H}_{2} \mathrm{~S}}$ isotopic signature.

\section{Geological Setting}

The Lavrion district has been the focus of intense research and numerous studies (e.g., Marinos and Petrascheck, 1956; Economou and Sideris, 1976; Papanikolaou and Syskakis, 1991; Bonsall et al., 2007; Skarpelis, 2007; Skarpelis et al., 2008; Baziotis et al., 2009). Two different Alpine nappes were distinguished locally (Fig. 1): The "Cyclades Blueschist Belt", at the base, which was initially a Mesozoic continental margin. It is composed of an underlying meta-volcanosedimentary sequence, i.e., comprises of Mesozoic neritic carbonates and overlying Tertiary meta-flysch and meta-clastic 
rocks (Kaesariani schists), sandwiched between the Upper and Lower marbles, at the top (Fig. 1) (Marinos and Petrascheck, 1956).

During the Tertiary, it experienced two episodes of regional metamorphism. The first occurred at $70 \mathrm{Ma}$, during collision between the Apulian microplate and Eurasia, and reached the blueschist to eclogite facies $\left(\mathrm{T}_{\max } \approx 450-550^{\circ} \mathrm{C}\right.$ and a $\mathrm{P}_{\max } \approx 12-18$ kbar; Bröcker and Pidgeon, 2007). This event was followed by an episode of greenschist to amphibolite facies metamorphism, at 25-18 Ma ( $\mathrm{T}_{\max }$ $\approx 450^{\circ}-480^{\circ} \mathrm{C}$ and $\left.\mathrm{P}_{\max } \approx 5-7 \mathrm{kbars}\right)$, which occurred as a result of isothermal decompression and exhumation (Wijbrans et al., 1993). Finally, contact metamorphism during Miocene was associated with the intrusion of the 8.3 to 11.9 Ma-old Plaka granodiorite and 7.3 Ma, felsic dykes and sills (Altherr and Siebel, 2002; Skarpelis et al., 2008).

The Cyclades Blueschist unit in the area is tectonically overlain by the "Upper unit" ophiolites i.e., a heterogeneous unit composed of unmetamorphosed Permian to Mesozoic sediments, intercalated ophiolitic fragments, Tertiary-greenschist facies rocks and Late-Cretaceous medium pressure-high temperature rocks (also called prasinites, Baltatzis, 1996; Photiades and Carras, 2001) (Fig. 1). It is separated from the Cyclades Blueschist unit by a detachment fault that formed during the early Miocene as back-arc extension dominated the Cyclades (Skarpelis, 2007). During this extensional period, granodioritic magmas intruded these units, and hornfels developed around the margins of the Plaka pluton (Skarpelis et al., 2008) (Fig. 1).

\section{Types of Sulfide Mineralization and Their Paragenesis}

There are several types of sulfide mineralization present in the Lavrion district, which are related to progressive decrease in temperature of formation: (i) porphyry-style, low-grade, molybdenite mineralization in the proximity of Plaka granodiorite, which occurs as quartz tension gashes and minor stockworks. It is associated with the potassic alteration assemblage of orthoclase-albite-sericitebiotite (Bonsall et al., 2007; Voudouris et al., 2008a, b), (ii) Ca-Fe skarn, hosted in schists and marbles located at the margins of Plaka pluton, with the assemblages magnetite and magnetite-hematite representing endoskarns (stage I), and pyrite-pyrrhotite and Fe-rich-sphalerite-pyrite-Ag-rich-galena $( \pm$ arsenopyrite-bismuthinite-chalcopyrite-mackinawite-glaucodote-native bismuth-scheelitetetradymite, $\mathrm{T} \leq 581 \pm 3^{\circ} \mathrm{C}$, Glatz, 1967) to form exoskarns (stage II) (Marinos and Petracheck, 1956; Leleu et al., 1973; Economou et al., 1981; Bonsall et al., 2007), (iii) breccia-porphyry dike mineralization which contains minor amounts of arsenopyrite, pyrite, magnetite, pyrrotite, Fe-rich sphalerite and chalcopyrite (stage I), galena, argentian tetrahedrite and tennantite, freibergite, wurtzite and enargite (stage II) and marcasite, argentian galena, and $\mathrm{Bi}-\mathrm{Cu}-\mathrm{Ag}-\mathrm{Pb}-\mathrm{Sn}$-sulfosalts (stage III) (Economou and Sideris, 1976; Bonsall et al., 2007; Voudouris et al., 2008a, b) and (vi) carbonatereplacement $\mathrm{Pb}-\mathrm{Zn}-\mathrm{Ag}$ mantos, chimney-orebodies and veins (e.g., vein 80 ) with the generalized assemblage: pyrite, arsenopyrite, pyrrhotite, loellingite, rammelbergite, sphalerite (with Fe $\geq 10$ wt. \%), greenockite, niccolite, laggisite, gerdorsfite and chalcopyrite (stage I), pyrite, argentian chalcopyrite and tetrahedrite, enargite, luzonite, freibergite, wurtzite (with $\mathrm{Fe} \leq 2 \mathrm{wt} . \%$ ), and galena (stage II), marcasite, argentian galena, bournonite, miargyrite, pyrargyrite-proustite ( $\mathrm{T} \geq 192^{\circ} \mathrm{C}$, Hall, 1966), stephanite, nuffeldite, argentite, polybasite, pearsite, chalcocite, stannite, petrukite, isotropic-orpiment $\left(\mathrm{T}=265 \pm 5^{\circ} \mathrm{C}\right.$, Hall and Yund, 1964), stibnite, native Bi, As and $\mathrm{Au}$, covellite, and Bi-Cu-Ag$\mathrm{Pb}-\mathrm{Sn}$-sulfosalts (cosalite, aikinite, lilianite, isotropic matildite, $\mathrm{T}=195 \pm 5^{\circ} \mathrm{C}$, (Craig, 1967), bismuthite, ramdohrite, semseyite, wittichenite, emplectite and mummeite (stage III). These ores are related to carbonatization of the schists and silicification of the marbles, and late formation of vein and vuggy fluorite, siderite and barite. These hypogene stages were followed by a supergene 
one (stage V) with more than fifty different minerals including, native Au and Ag (Skarpelis and Ardyraki, 2008).

\section{Samples and Methods}

Material for stable isotope studies was obtained from calcite intergrown with $\mathrm{Pb}-\mathrm{Zn}-\mathrm{Ag}$ sulfides, as well as smithsonite, cerussite, aragonite, and pyrite, sphalerite and galena, from the Ca-Fe skarns, carbonate-replacement ores. Additionally, late barite and gypsum, host marbles and Plaka granodiorite and associated porphyritic dikes and sills were sampled. Samples were collected from underground and surface locations at Plaka, Kamariza, Sounio, Esperanza, Adame, Avlaki, Villia, Megala Pefka, Christina, and Sounio deposits. All minerals analyzed were hand picked and checked under a binocular microscope to ensure a purity of $>95 \%$. Isotopic compositions of oxygen and carbon were analyzed on a Thermo-Finnigan Delta-Plus XL mass spectrometer, at the Stable Isotope Research Facility, Indiana University. Carbon and oxygen in carbonates were liberated as $\mathrm{CO}_{2}$ by treating the samples with $100 \%$ phosphoric acid at $75^{\circ} \mathrm{C}$ (Clayton et al., 1989, in Lefticariu et al., 2006). Sulfur was released as $\mathrm{SO}_{2}$ from sulfides and sulfates by heating samples to $1,100^{\circ} \mathrm{C}$ in the presence of $\mathrm{CuO}$ (Fritz et al., 1974, Lefticariu et al., 2006) and then, measured using a Finnigan MAT 252 mass spectrometer. The isotopic ratios are reported in standard $\delta$ notation per mil relative to V-SMOW for oxygen, V-PDB for carbon, and V-CDT for sulfur. Analytical precision was better than \pm 0.05 per mil.

\section{Conditions of Emplacement of the Plaka Pluton}

In order to estimate the conditions of emplacement of the Plaka pluton, we have used the amphibole geobarometer (based on the variation in the $\mathrm{Al}^{\text {tot }}$ content of the amphibole as a function of pressure), utilizing the experimental calibrations of Schmidt (1992). The composition of the analyzed amphiboles varies from the crystals core to the rim from $1.21\left(\mathrm{Al}_{2} \mathrm{O}_{3}=7.06\right.$ wt. \%) to $0.87\left(\mathrm{Al}_{2} \mathrm{O}_{3}=5.99\right.$ wt. \%), which mirrors ascent of the granodiorite magma. The spectrum of the calculated pressure values ranges between 2.75 to 1.15 kbars. Temperatures of crystallization were calculated by using the Vyhnal et al. (1991) geothermometer which is a function of the pressure. The calculated temperatures range between $725^{\circ}$ and $685^{\circ} \mathrm{C}$ for the above pressure values.

\section{Carbon and Oxygen Isotopes}

Twelve carbon and oxygen isotope analyses were obtained from calcite in the carbonate-replacement mineralization and five metamorphic calcite from the Upper and Lower Marbles. Ten additional isotopic values for calcite are from Bosnall et al. (2007) and fifteen of cerrusite, late aragonite and phosgenite from Gilg and Boni (2004).

Calcite in carbonate-replacement from Kamariza, Villia, Esperanza, Adame and M. Pefka deposits displays values of $\delta^{13} \mathrm{C}=-8.6$ to -3.1 and $\delta^{18} \mathrm{O}=18.4$ to $34, \delta^{13} \mathrm{C}=-11.8$ to -8.3 and $\delta^{18} \mathrm{O}=34.0$ to 38.7 to, $\delta^{13} \mathrm{C}=-13.5$ to -1.4 and $\delta^{18} \mathrm{O}=18.0$ to $28.6, \delta^{13} \mathrm{C}=-12.0$ to -2.0 and $\delta^{18} \mathrm{O}=21.2$ to 26.1 , and $\delta^{13} \mathrm{C}$ $=-15.6$ and $\delta^{18} \mathrm{O}=18$ per mil, respectively. Based on the calcite-water and $\mathrm{CO}_{2}$-water equations of Ohmoto and Rye (1979), the calculated isotopic values, for the same locations, were: $\delta^{13} \mathrm{C}_{\mathrm{CO}_{2}}=-6.7$ to -2.2 and $\delta^{18} \mathrm{O}_{\mathrm{H}_{2} \mathrm{O}}=8.9$ to 26.2 (at $400^{\circ}, 350^{\circ}, 320^{\circ}, 300^{\circ}, 250^{\circ}$ and $200^{\circ} \mathrm{C}$ ), $\delta^{13} \mathrm{C}_{\mathrm{CO}_{2}}=-9.3$ to -5.8 and $\delta^{18} \mathrm{O}_{\mathrm{H}_{2} \mathrm{O}}=4.2$ to 8.9 (at $300^{\circ} \mathrm{C}$ ), $\delta^{13} \mathrm{C}_{\mathrm{CO}_{2}}=-10.8$ to -4.4 and $\delta^{18} \mathrm{O}_{\mathrm{H}_{2} \mathrm{O}}=13.7$ to 24.3 (at $320^{\circ} \mathrm{C}$ ), $\delta^{13} \mathrm{C}_{\mathrm{CO}_{2}}=-9.2$ to 0.8 and $\delta^{18} \mathrm{O}_{\mathrm{H}_{2} \mathrm{O}}=16.2$ to 21.2 (at $350^{\circ} \mathrm{C}$ ), and $\delta^{13} \mathrm{C}_{\mathrm{CO}_{2}}=-13.7$ and $\delta^{18} \mathrm{O}_{\mathrm{H}_{2} \mathrm{O}}=26.6$ per mil (at $300^{\circ} \mathrm{C}$ ) (Fig. 2).

Calcite in the Upper and Lower marbles display measured isotope values of $\delta^{13} \mathrm{C}=-6.7$ to -2.8 and 


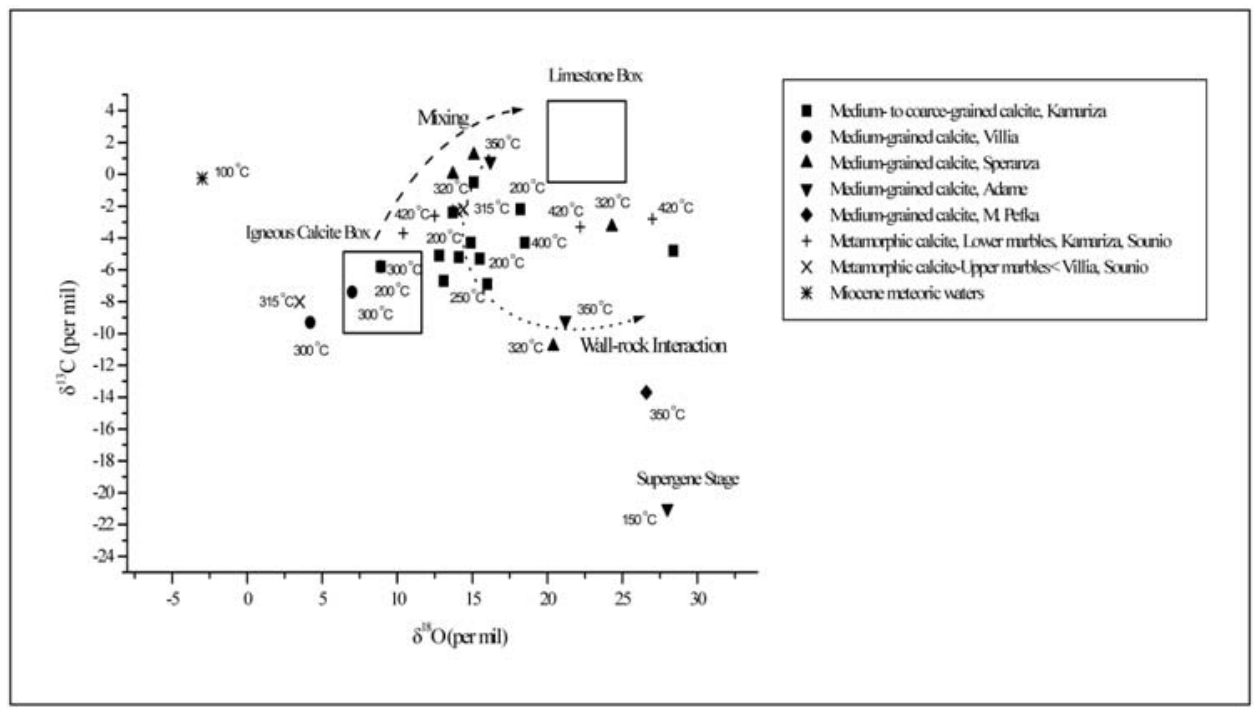

Fig. 2: Carbon versus oxygen isotope diagram for hydrothermal and metamorphic calcite showing stable isotope systematics of hydrothermal fluids from Kamariza, Villia, Speranza, Adame, M. Pefka, Lavrion deposits (the marine limestone and "igneous calcite" boxes after Bowman (1998) are indicated and the estimated $\delta^{18} \mathrm{O}$ and $\delta^{13} \mathrm{C}$ values of Miocene-age meteoric water for southern Europe from Zachos et al., 2001).

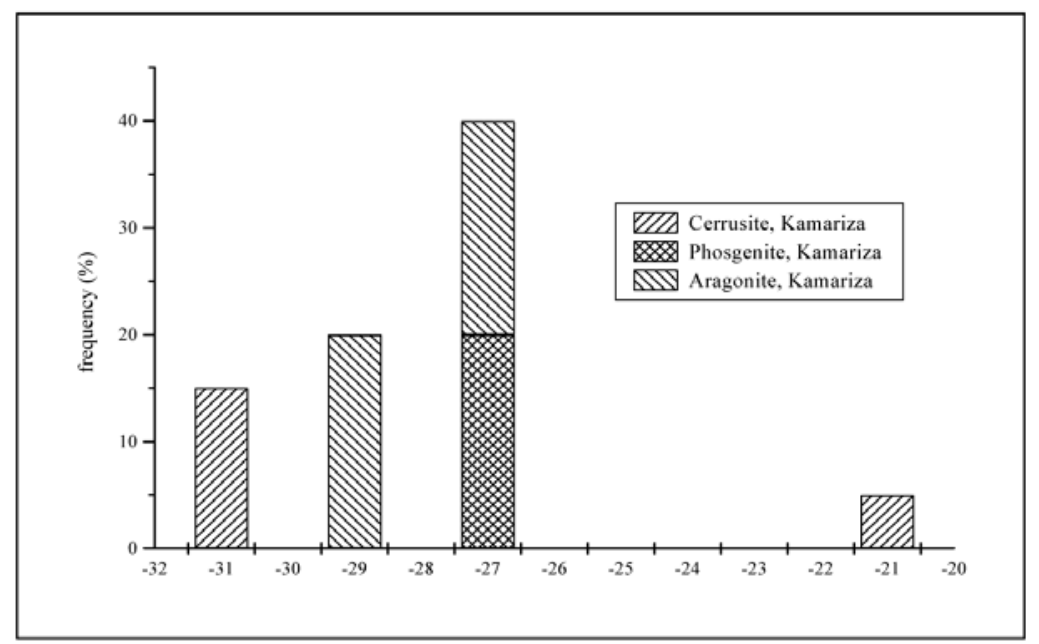

Fig. 3: Histogram of the frequency of the $\delta^{18} \mathrm{O}_{\mathrm{H} 2 \mathrm{O}}$ values of cerussite, aragonite and phosgenite from the Kamariza deposits.

$\delta^{18} \mathrm{O}=13.2$ to 29.8 per mil (Lower marble from Kamariza and Sounio deposits) and $\delta^{13} \mathrm{C}=-10.9$ to -4.8 and $\delta^{18} \mathrm{O}=27.7$ to 28.4 per mil (Upper marble from Villia and Sounio). Based on the same equations of O'Neil et al., (1969) and Ohmoto and Rye (1979), the calculated isotopic values were: $\delta^{13} \mathrm{C}=-3.7$ to -2.6 and $\delta^{18} \mathrm{O}=10.4$ to 27.0 (Lower marble, at $420^{\circ} \mathrm{C}$; obtained from Knoll, 1988), and $\delta^{13} \mathrm{C}=-8.0$ to -2.3 and $\delta^{18} \mathrm{O}=3.5$ to 14.6 (at $315^{\circ} \mathrm{C}$ ), $\delta^{13} \mathrm{C}=-10.8$ to -4.4 and $\delta^{18} \mathrm{O}=13.7$ to 24.3 (at $320^{\circ} \mathrm{C}$; obtained from Knoll, 1988) (Fig. 2). 


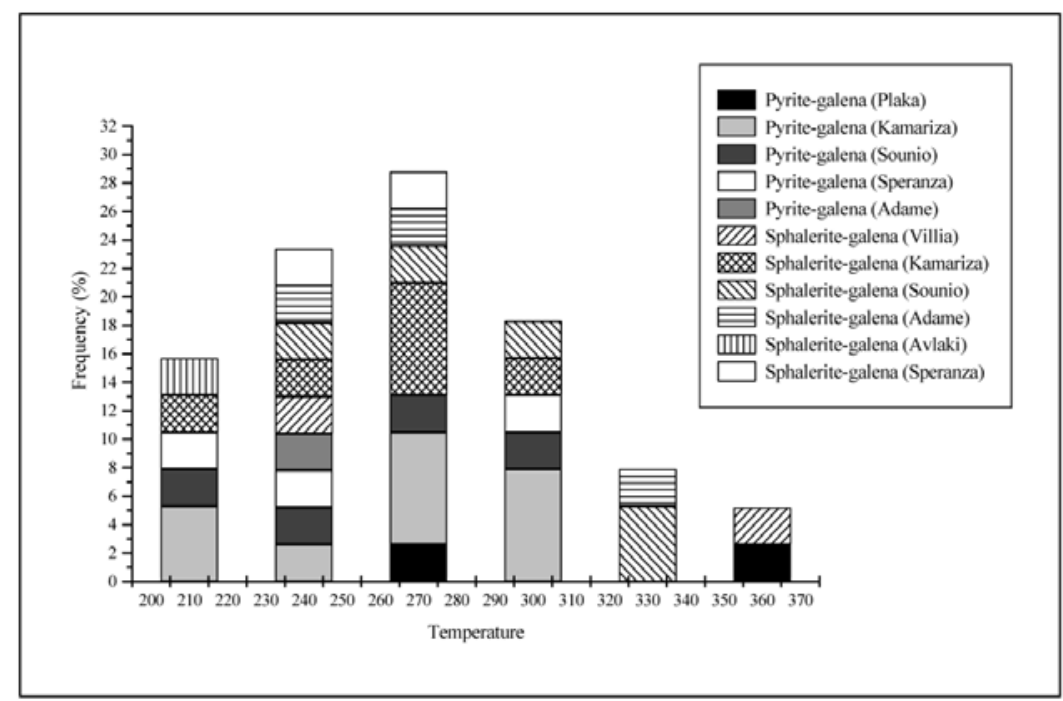

Fig. 4: Histogram of the frequency of the temperature values obtained by isotope geothermometry from the Plaka, Kamariza, Sounio, Speranza, Adame, Villia and Avlaki deposits.

Finally, the isotopic compositions of cerussite, aragonite and phosgenite range from $\delta^{18} \mathrm{O}=-25.9$ to 24.6 (some of the measured values were adopted from Gilg and Boni, 2004, and are for the Kamariza and Adame deposits), $\delta^{18} \mathrm{O}=30.0$ to 33.0 and $\delta^{18} \mathrm{O}=27.1$ to 28.7 per mil (both from Kamariza). These correspond to isotopic calculated values of $\delta^{18} \mathrm{O}_{\mathrm{H}_{2} \mathrm{O}}$ that range from 17.1 to 32.8, 26.2 to 27.3 and 27.0 to 29.0 per mil (at $100^{\circ} \mathrm{C}$ ) (Fig. 3).

\section{Oxygen and Hydrogen Isotopes}

Oxygen and hydrogen isotope compositions of quartz from Plaka granodiorite range from 6.8 to 9.1 and from -70 to -78 per mil (one measured value was obtained by Altherr et al., 1988). These correspond to calculated $\delta^{18} \mathrm{O}_{\mathrm{H}_{2} \mathrm{O}}$ fluid values of 5.3 to 5.9 per mil and -55 to -62 per mil, at $700^{\circ} \mathrm{C}$. The $\delta^{18} \mathrm{O}$ and $\delta \mathrm{D}$ values from quartz in skarn of 10.8 and -76 per mil corresponds to $\delta^{18} \mathrm{O}_{\mathrm{H}_{2} \mathrm{O}}=3.2$ per mil and $\delta D_{\mathrm{H}_{2} \mathrm{O}}=-67$, at $500^{\circ} \mathrm{C}$ (Baltatzis, 1981).

\section{Sulfur Isotope Study and Temperature of Sulphide Deposition}

Temperature determinations for primary sulphide deposition based on $\delta^{34} \mathrm{~S}$ isotopes, were obtained for the isotopic coexistence of the pyrite-galena and sphalerite-galena pairs according to the equations of Ohmoto and Lasaga (1982). The calculated temperatures during sulphide deposition range between $358^{\circ}$ to $306^{\circ} \mathrm{C}$ for Plaka, to $359^{\circ}$ to $225^{\circ} \mathrm{C}$ for Kamariza, $350^{\circ}$ to $260^{\circ} \mathrm{C}$ for Villia, $300^{\circ}$ to $225^{\circ} \mathrm{C}$ for Adame, $320^{\circ}$ to $220^{\circ} \mathrm{C}$ for Sounio, $300^{\circ}$ to $225^{\circ} \mathrm{C}$ for Speranza, and $\sim 200^{\circ} \mathrm{C}$ for Avlaki (Fig. 4).

$\mathrm{A} \delta^{34} \mathrm{~S}$ isotope value obtained from arsenopyrite in the skarn (high temperature mineralization, Plaka area) is 7.3 per mil, which corresponds to a calculated value of $\delta^{34} S_{\mathrm{H} 2 \mathrm{~S}}$ of 6.8 per mil (based on the arsenopyrite- $\mathrm{H}_{2} \mathrm{~S}$ equation of Ohmoto and Lasaga, 1982 , at $\mathrm{T}=400^{\circ} \mathrm{C}$, Economou et al., 1981) (Fig. 5). The $\delta^{34} \mathrm{~S}$ measured isotopic values of pyrite from Plaka, Villia, Kamariza, Sounio, Speranza and M. Pefka locations display a range of $\delta^{34} \mathrm{~S}$ values of -2.6 to $3.9,4.3$ to $5.7, \approx 1.3,-3.2$ to $-0.4,-1.8$ to $-0.9,-3.7$ to $4.5, \approx 0.4$ and $\approx-2.7$ per mil, respectively. Based on the equations for pyrite- $\mathrm{H}_{2} \mathrm{~S}$ of 


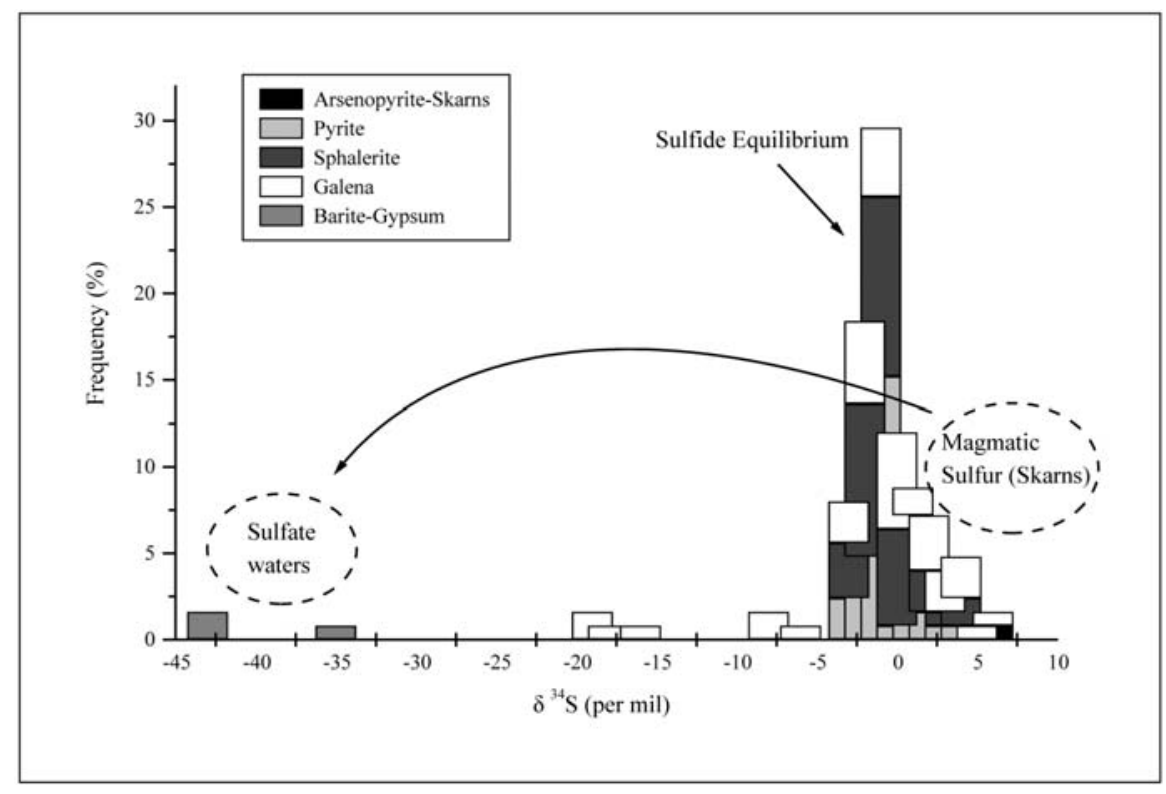

Fig. 5: Histogram of the frequency of the $\delta^{34} S_{\mathrm{H} 2 \mathrm{~S}}$ values of arsenopyrite, pyrite, sphalerite, galena, barite and gypsum from the Plaka, Sounio, Kamariza, M. Pefka, Spiliazeza, Speranza, Villia, Adame, Sounio, Christina, Avlaki deposits.

Ohmoto and Rye (1979) and Ohmoto and Lasaga (1982), the calculated $\delta^{34} \mathrm{~S}_{\mathrm{H}_{2} \mathrm{~S}}$ values are -1.6 to $2.9,3.2$ to $4.6, \approx 0.3,-2.1$ to $0.8,-2.8$ to $-0.2,-1.5$ to $2.2, \approx-0.7$ and $\approx-1.2$ per mil, in the fluid, at $\mathrm{T}$ $=200^{\circ}, 250^{\circ}, 300^{\circ}, 320^{\circ}$ and $350^{\circ} \mathrm{C}$ (Fig. 5).

Values of $\delta^{34} \mathrm{~S}$ of sphalerite from Villia, Adame, Kamariza, Sounio, Spiliazeza, Speranza, Christina and M. Pefka exhibit a range from 4.2 to $4.8,-1.6$ to $1.6,-3.7$ to $-1.1,-2.8$ to $-1.2,-3.9$ to $1.3,0.6$ to $4.1, \approx-1.4$ and $\approx 9.4$ per mil, respectively. The calculated values for the isotopic composition of the fluid (based on the sphalerite- $\mathrm{H}_{2} \mathrm{~S}$ equation of Ohmoto and Rye, 1979; Ohmoto and Lasaga, 1982) were $\delta^{34} \mathrm{~S}_{\mathrm{H}_{2} \mathrm{~S}}=3.9$ to $4.5,-1.8$ to $1.4,-3.3$ to $-0.8,-2.4$ to $-0.7,-3.3$ to $-0.7,0.4$ to $3.7, \approx-1.0$, and $\approx$ 9.1 per mil, at the same temperatures, respectively (Fig. 5). The $\delta^{34} S$ values for galena from Plaka, Villia, Adame, Kamariza, Sounio, Speranza, and Avlaki range from -3.3 to 4.1, 2.3 to 3.9, -3.4 to 1.5, -4.7 to $-0.4,-5.0$ to $2.6,0.2$ to 1.7 and 2.7 to 3.6 per mil, respectively. The calculated values (based on the galena- $\mathrm{H}_{2} \mathrm{~S}$ equation of Ohmoto and Rye, 1979; Ohmoto and Lasaga, 1982) were $\delta^{34} \mathrm{~S}_{\mathrm{H}_{2} \mathrm{~S}}=-$ 2.5 to $6.0,4.1$ to $5.6,-1.8$ to $1.6,-2.8$ to $1.7,-8.5$ to $-1.1,2.0$ to 3.5 and -0.2 to 1.7 per mil, at the same temperatures (Fig. 5).

Finally, sulfur isotope compositions of barite and gypsum from the Kamariza and Sounio deposits reveal values of $\delta^{34} S$ which range from $\delta^{34} S=17.3$ to 20.4 and $\approx 23.5$, and $\approx 0.2$ per mil, corresponding to calculated $\delta^{34} \mathrm{~S}_{\mathrm{H}_{2} \mathrm{~S}}$ of -19.5 to $-16.4, \approx-35.0$ and $\approx-43.6$ per mil (based on the barite$\mathrm{H}_{2} \mathrm{~S}$ and gypsum- $\mathrm{H}_{2} \mathrm{~S}$ equations of Kusakabe and Robinson, 1977 and Ohmoto and Rye, 1979, at $\mathrm{T}=200^{\circ}, 150^{\circ}$ and $100^{\circ} \mathrm{C}$ ) (Fig. 5).

Calculations of water-to-rock ratios were performed by assuming a closed system for the early mineralized stages, at $\mathrm{T} \geq 300^{\circ} \mathrm{C}$ (as evidenced by the occurrence of calcite veins mainly as stockworks), and an open system for the late ones, at $\mathrm{T} \leq 300^{\circ} \mathrm{C}$. Calculations were achieved by using the equa- 
tions adopted from Taylor (1974). The calculated isotopic compositions reveal water-to-rock ratios with values of, 6.6 to $10.1 \%$ (for Villia), 8.5\% (for Adame), 8.9 to $52.6 \%$ (for Kamariza), 29.6\% (for Speranza), $40.3 \%$ (for Sounio) and 2.6\% (for Plaka).

\section{Discussion and Conclusions}

Oxygen and carbon isotope data suggest multiple sources for the ore fluid, i.e., magmatic and metamorphic (Fig. 2). There is a recognizable depletion in $\delta^{13} \mathrm{C}$ and $\delta^{18} \mathrm{O}$ values which can be the result of interaction of modified high-temperature magmatic fluids with the hosts or to have formed under medium to high water-to-rock ratios, i.e., 4.8 to $52.6 \%$. This depletion is also correlated to simple cooling of the fluid, from $400^{\circ}$ to $150^{\circ} \mathrm{C}$, which was caused by mixing of the Ag-bearing fluid with meteoric waters had entered the highly permeable carbonate-host.

The oxygen and hydrogen isotope compositions are consistent with magmatic water composition, and are similar to those characterizing the Tinos, Mykonos and Serifos granitoids and skarns (Tombros et al., 2007, 2008; Tombros, 2009 and St. Seymour et al., 2009a, b). However, granitoids in Lavrion area are weakly affected by alteration (e.g., silicification, propylitization, carbonatization, and sericitization, Bonsall et al., 2007) due to their interaction with the mineralizing fluids; as it was depicted from the $\delta \mathrm{D}_{\mathrm{H}_{2} \mathrm{O}}$ values of the Plaka granitoid. For the early stages of Lavrion ores the calculated $\delta^{18} \mathrm{O}_{\mathrm{H}_{2} \mathrm{O}}$ and $\delta \mathrm{D}_{\mathrm{H}_{2} \mathrm{O}}$ isotopic values reflect the dominance of a magmatic component, whereas the late-stage fluids are consistent with isotopic exchange of the mineralizing fluid with Miocenic meteoric waters.

The mixing hypothesis of the fluid is also supported by the $\delta^{34} \mathrm{~S}_{\mathrm{H} 2 \mathrm{O}}$ data: The calculated $\delta^{34} \mathrm{~S}_{\mathrm{H}_{2} \mathrm{O}}$ compositions of sulfides i.e., $\delta^{34} \mathrm{~S}_{\mathrm{H}_{2} \mathrm{O}}=-8.0$ to 9.0 per mil from the Lavrion deposits are interpreted to reflect a double source. The positive $\delta^{34} \mathrm{~S}_{\mathrm{H}_{2} \mathrm{O}}$ values could have been the result of the direct addition of magmatic volatiles to the hydrothermal fluid (e.g., $\delta^{34} \mathrm{~S}_{\mathrm{H}_{2} \mathrm{O}}=6.8$ per mil from skarn-arsenopyrite). The negative $\delta^{34} \mathrm{~S}_{\mathrm{H}_{2} \mathrm{O}}$ values can be explained by the introduction of isotopically light sedimentary sulfur into the hydrothermal system from the enclosing metasedimentary rocks, at higher $\log f \mathrm{O}_{2}$ conditions. Sulfur isotope compositions $\delta^{34} \mathrm{~S}_{\mathrm{H}_{2} \mathrm{O}}$ of barite and gypsum from carbonate-replacement ores, range from -43.6 to -16.4 to per mil and reflect seawater sulfate values of Miocene (e.g., -40 to -20 per mil, Ohmoto and Rye, 1979).

Temperatures based on $\delta^{34} \mathrm{~S}$ pyrite-galena and sphalerite-pyrite pairs revealed at least three thermal pulses during deposition of the carbonate-replacement ore: (i) $\sim 360^{\circ}$, (ii) $320^{\circ}-280^{\circ}$ and (iii) $260^{\circ}$ to $200^{\circ} \mathrm{C}$. Telescoping phenomena i.e., co-existence of minerals which belong to different paragenetic stages is apparent in the Lavrion ores. This can be explained by the protracted period of the oreforming event of more than $2 \mathrm{Ma}$ (10 to $8 \mathrm{Ma}$, Skarpelis, 2007). A primary closed, channelized hydrothermal system was operational in Lavrion in the early stages resulted in As-rich skarn deposits $\left(\mathrm{T} \leq 500^{\circ} \mathrm{C}\right)$. Then, the hydrothermal system in the late stages of its evolution had opened $\left(\mathrm{T} \geq 100^{\circ} \mathrm{C}\right)$, and resulted in the precipitation of fluorite-barite ores.

\section{References}

Altherr, R., and Siebel, W. 2002. I-type plutonism in a continental back-arc setting: Miocene granitoids and monzonites from the central Aegean Sea, Greece. Contributions to Mineralogy and Petrology, $143,397-415$.

Baltatzis, E. 1981. Contact metamorphism of a calcilicate hornfels from Plaka area, Lavrium, Greece. Neues Jahrbuch für Mineralogie Monatshefte, 11, 481-488. 
Baltatzis, E. 1996. Blueschist-to-greenschist transition and the P-T path of prasinites from the Lavrion area, Greece: Mineralogical Magazine, 60, p. 551-561.

Baziotis, I., Proyer, A., and Mposkos, E., 2009, High-pressure/low-temperature metamorphism of basalts in Lavrion (Greece): Implications for the preservation of peak metamorphic assemblages in blueschists and greenschists: European Journal of Mineralogy, 21, 133-148.

Bonsall, T.A., Spry, P.G., Voudouris, P., St. Seymour, K., Tombros, S., and Melfos, V. 2007. Fluid inclusion and stable isotope characteristics of carbonate replacement $\mathrm{Pb}-\mathrm{Zn}-\mathrm{Ag}$ deposits in the Lavrion district, Greece. In Andrews, C.J., et al., eds., Mineral exploration and research: Digging deeper, Irish Association for Economic Geology, Dublin, 283-286.

Bowman, J.R. 1998. Stable-isotope systematics of skarns. In Lentz, D.R., ed., Mineralized intrusion-related skarn systems, Mineralogical Association of Canada Short Course Series, 26, 99-145.

Bröcker, M., and Pidgeon, R.T. 2007. Protolith ages of meta-igneous and metatuffaceous rocks from the Cycladic Blueschist Unit, Greece: Results of a reconnaissance U-Pb zircon study. Journal of Geology, 115, 83-98.

Conofagos, C. 1980. The Lavrion and the ancient Greek techniques for silver production. Athens, Ekdotiki Athinon, $458 \mathrm{p}$.

Clayton, R.N., Goldsmith, J.R., and Mayeda, T.K. 1989. Oxygen isotope fractionation in quartz, albite, anorthite and calcite. Geochimica et Cosmochimica Acta, 53, 725-733.

Craig, J.R. 1967. Phase relations and mineral assemblages in the Ag-Bi-Pb-S system. Mineralium Deposita, 1, 278-306.

Economou, M., and Sideris, C. 1976. A mineralized brecciated granodiorite porphyry in the Laurium mines, Greece. Neues Jahrbuch für Mineralogie Abhandlungen, 128, 209-218.

Economou, M., Skounakis, S., and Papathanasiou, C. 1981. Magnetite deposits of skarn type from the Plaka area of Laurium, Greece. Chemie der Erde, 40, 241-252.

Fritz, P., Drimmie, R.J., and Norwick, K. 1974. Preparation of sulfur dioxide for mass spectrometer analysis by combustion of sulfide with copper oxide. Analytical Chemistry, 76, 164-166.

Glatz, A.C., 1967. The $\mathrm{Bi}_{2} \mathrm{Te}_{3}-\mathrm{Bi}_{2} \mathrm{~S}_{3}$ system and the synthesis of tetradymite. American Mineralogist, 52 , 161-170.

Gilg, H.A. and Boni, M., 2004, Stable isotope studies on $\mathrm{Zn}$ and $\mathrm{Pb}$ carbonates: Could they play a role in mineral exploration? In: Applied Mineralogy, Developments in Science and Technology, Pecchio, M., Andrade, F.R.D., D’Agostino, L.Z., Kahn, H., Sant'Agostino, L.M., Tassinari, M.M.M.L., (eds), ICAM-BR, São Paulo, 2, 781-784.

Hall, H.T., 1966. The systems Ag-Sb-S, Ag-As-S and Ag-Bi-S: Phase relations and mineralogical significance. $\mathrm{PhD}$ Thesis, Brown University, 240 p.

Hall, H.T., and Yund, 1964. Equilibrium relations among some silver sulfosalts and arsenic sulfides. American Geophysical Union Translations, 45, 1311-1321.

Kalogeropoulos, S.I., and Mitropoulos, P. 1983. Fluid inclusion characteristics of fluorite from Lavrion (Greece). Annales Geologiques des Pays Helleniques, 31, 130-135.

Knoll, O. 1988. Ore mineralogy and fluid inclusion studies of Pb-Zn-ores from Lavrion-Greece. MSc Thesis, Hamburg, University of Hamburg, 72 p.

Kusakabe, M., and Robinson, B. 1977. Oxygen and sulfur isotope equilibria in the $\mathrm{BaSO}_{4}-\mathrm{HSO}_{4}-\mathrm{H}_{2} \mathrm{O}$ system from $110^{\circ}$ to $350^{\circ} \mathrm{C}$ and applications. Geochimica and Cosmochimica Acta, 41, 1033-1040.

Lefticariu, L., Pratt, L. M., and Ripley, E. M. 2006. Mineralogic and sulfur isotope effects accompanying the oxidation of pyrite in millimolar solutions of hydrogen peroxide at temperatures from 4 to $150{ }^{\circ} \mathrm{C}$. Geochimica et Cosmochimica Acta, 70, 4889-4905. 
Leleu, M. 1966. Les gisements plombo-zincifres du Laurium (Grèce). Sciences de la Terre, 9, 293-343.

Leleu, M., Morikis, A., and Picot, P. 1973. Sur des mineralisations de type skarn au Laruium (Grèce). Mineralium Deposita, 36, 477-489.

Marinos, G. and Petrascheck W.E. 1956. Larium: Geological and geophysical research. Institute for Geology and Subsurface Research, 4, 1-246.

Melidonis, N.G., 1980. The geological structure and mineral deposits of Tinos Island (Cyclades, Greece): A preliminary study. Institute of Geology and Mineral Exploration, 13, 1-80.

Ohmoto, H., and Lasaga, A.C. 1982. Kinetics of reactions between aqueous sulfates and sulfides in hydrothermal systems. Geochemica Et Cosmochimica Acta, 46, 1727-1745.

Ohmoto, H., and Rye, R.O. 1979. Isotopes of sulfur and carbon: In Barnes, H.L. (ed.), Geochemistry of hydrothermal ore deposits, $2^{\text {nd }}$ ed., New York, Wiley Interscience, 509-567.

Papanikolaou, D., and Syskakis, D. 1991. Geometry of acid intrusive in Plaka, Laurion and relation between magmatism and deformation. Bulletin of the Geological Society of Greece, 25, 45-67.

Photiades, A. and Carras, N. 2001. Stratigraphy and geological structure of the Lavrion area (Attica, Greece). Bulletin of the Geological Society of Greece, 34, 103-109.

Salemink, J. 1985. Skarn and ore formation at Seriphos, Greece, as a consequence of granodiorite intrusion. Geologica Untrajectina, 40, 1-231.

Skarpelis, N. 2002. Geodynamics and evolution of the Miocene mineralization in the Cycladic-Pelagonian Belt, Hellenides. Bulletin of the Geological Society of Greece, 34, 2191-2209.

Skarpelis, N. 2007. The Lavrion deposit (SE Attica, Greece): geology, mineralogy and minor elements chemistry. Neues Jahrbuch für Mineralogie Abhandlungen, 183, 227-249.

Skarpelis, N., and Ardyraki, A. 2008. Geology and origin of supergene ore at the Lavrion Pb-Ag-Zn deposit, Attica, Greece. Resource Geology, 59, 1-14.

Skarpelis, N., Tsikouras, B., and Pe-Piper, G. 2008. The Miocene igneous rocks in the Basal unit of Lavrion (SE Attica, Greece): Petrology and geodynamic implications. Geological Magazine, 145, 1-15.

Schmidt, M.W. 1992. Amphibole composition in tonalite as a function of pressure: an experimental calibration of the Al-in-hornblende barometer. Contributions to Mineralogy and Petrology, 110, 304-310.

St. Seymour, K., Zouzias, D., Tombros, S.F., and Kolaiti, E. 2009a. The geochemistry of the Serifos pluton and associated iron oxide and base metal sulphide ores: Skarn or metamorphosed exhalite deposits? Neues Jahrbuch für Mineralogie Abhandlungen (DOI: 10.1127/0077-7757/2009/0143).

St. Seymour, K., Mastrakas, N., Tombros, S.F., Spry, P.G., Denes, G., and Kranidiotis, P. 2009b. Scheelite mineralization of the skarn deposit, at Tinos Island, Aegean Sea, Cyclades. Neues Jahrbuch für Mineralogie Abhandlungen, 186, 37-50.

Tombros, St., 2009. Prospecting for Au-Ag-Te mineralization in the Cyclades, based on the example of Tinos Island. "Pythagoras II", Post-doctoral Fellowship, Operational Program for Educational and Vocational Training II (EPEAEK II), Univ. of Patras, 940 p.

Tombros, S.F., Seymour, K., Spry, P.G., and Williams-Jones, A. 2008. Later stages of evolution of an epithermal system: Au-Ag Mineralizations at Apigania Bay, Tinos Island, Cyclades, Hellas (Greece). Mineralogy and Petrology, 94, 175-194.

Tombros, S.F., Seymour, K., Williams-Jones, A., and Spry, P. 2007. The genesis of epithermal Au-Ag-Te mineralization, Panormos Bay, Tinos Island, Cyclades, Greece. Economic Geology, 102, 1269-1294.

Vyhnal, C.R.; McSween, H.Y.Jr. and Speer, J.A. 1991. Hornblende chemistry in southern Appalachian granitoids: Implications for aluminium hornblende thermobarometry and magnetic epidote stability. American Mineralogist, 76, 176-188. 
Voudouris, P., Melfos, V., Spry, P. G., Bonsall, T., Tarkian, M., and Solomos, C. 2008a. Mineralogical and fluid inclusion study of the Kamariza carbonate-replacement deposit, Lavrion, Greece. Mineralogy and Petrology, 94, 85-106.

Voudouris, P., Melfos, V., Spry, P. G., Bonsall, T., Tarkian, M., and Economou-Eliopoulos, M. 2008 b. Mineralogical study and constraints on fluid evolution in the Plaka-related ore system, Lavrion, Greece. Mineralogy and Petrology, 93, 79-110.

Wijbrans, J.R., Van Wees, J.D., Stephenson, R.A., and Cloetingh, S.A.P.L. 1993. Pressure-temperaturetime evolution of the high-pressure metamorphic complex of Sifnos, Greece. Geology, 21, 443-446.

Zachos, J., Pagani, M., Sloan, L., Thomas, E., and Billups, K., 2001, Trends, rhythms, and aberrations in global climate 65 Ma to present: Science, 292, p. 686-693. 